J. Appl. Glycosci., 56, 247-251 (2009)

(C) 2009 The Japanese Society of Applied Glycoscience

Regular Paper

\title{
Gelatinization and Retrogradation Behavior of Potato Starch Controlled with Vegetable Sera
}

(Received March 30, 2009; Accepted July 1, 2009)

\author{
Yuriko Takamura, ${ }^{1, *}$ Kaoru Kinoshita, ${ }^{1, *}$ Azusa Ito, ${ }^{1, *}$ Makoto Hattori, ${ }^{1}$ Tadashi Yoshida, ${ }^{1}$ \\ Takahiro Inakuma ${ }^{2}$ and Koji Takahashi,** \\ ${ }^{1}$ Department of Applied Biological Science, Faculty of Agriculture, Tokyo University of Agriculture and Technology \\ (3-5-8, Saiwai-cho, Fuchu, Tokyo 183-8509, Japan) \\ ${ }^{2}$ Biogenics Division, Research Institute, Kagome Co., Ltd. (30, Nishi-toyama, Nasushiobara, Tochigi 329-2762, Japan)
}

\begin{abstract}
The particular effect of vegetable sera having different charged free amino acid contents prepared from tomato, carrot and red bell pepper on the gelatinization and retrogradation behavior of potato starch was analyzed from the results evaluated by differential scanning calorimetry, rapid viscoanalysis and transparency. The gelatinization temperature (GT) of potato starch increased with increasing added amounts of each vegetable serum, and this increased GT was almost completely dependent on the charged amino acid content of the vegetable serum. A small addition of each vegetable serum markedly reduced the peak viscosity and breakdown, and increased the pasting temperature due to the inhibition of swelling. Adding vegetable sera resulted in increased setback and turbidness, and in reduced enthalpy change for re-gelatinization to about 50-60\% of that of the control without any vegetable serum, suggesting that the vegetable sera reduced reconstitution of the ordered structure and caused subsequent entanglement and aggregation of the dispersed starch chains during cooling.
\end{abstract}

Key words: starch, vegetable serum, charged amino acid, gelatinization and retrogradation behavior, thermal property control

It is important to control the gelatinization and retrogradation behavior of starch that occurs during heating and cooling, because the quality of starchy food is strongly influenced by a change in the physical properties of native or gelatinized starch arising from the heat treatment. For example, gelatinized and swollen starch granules frequently breakdown under shear stress, resulting in the development of a sticky and pasty texture that is often disliked in starchy food. Retrogradation of the gelatinized starch causes degradation of the physical properties, a decrease in the quality of starchy food, and a shortened storage life. Many coexisting substances such as salts, ${ }^{1-6)}$ carbohydrates, ${ }^{1,6,7)}$ alcohols, ${ }^{8,9)}$ fatty acids, ${ }^{10)}$ surfactants, ${ }^{6,11)}$ organic acids, ${ }^{9)}$ amino acids and peptides ${ }^{12-16)}$ and compound substances ${ }^{17)}$ influence the gelatinization and retrogradation behavior of starch in terms of the gelatinization temperature (GT), crystallinity, viscosity, swelling, digestibility, transparency and texture. We have specifically paid attention to amino acids and peptides as coexisting substances, because little attention has been paid to applying them to control the thermal properties of starch, although amino acids and peptides are widely accepted for food use. We have already reported that lysine (Lys), glutamic acid (Glu) and $\varepsilon$-poly(L-lysine) (PL) with a positive or negative net charge had a marked effect of increasing GT and decreasing the viscosity and swelling, whereas glycine (Gly) and alanine (Ala), both with a zero net charge, had

\footnotetext{
${ }^{*}$ Equally contributed.

** Corresponding author (Tel. +81-42-367-5712, Fax. +81-42360-8830, E-mail: k-taka@cc.tuat.ac.jp).
}

little effect, and that the controlling effect of amino acids and PL on GT was substantially reversible during the amino acid- or PL-treatment and subsequent washing with water. ${ }^{13)}$ Furthermore, it has been clarified that the effect strongly depended on the absolute value of the amount of their net charge on the basis of the results from using PL with different degrees of polymerization. ${ }^{14)}$ Such notable control by an amino acid has been demonstrated to be due to the binding strength of the amino acid to the starch chains. ${ }^{15)}$ It has also been clarified that the addition of two different kinds of amino acid such as Glu and Lys revealed the synergistically increasing effects of each amino acid on GT, whereas coupling amino acids with a zero net charge showed little change in GT. ${ }^{16)}$ These results suggest that amino acid- or peptide-rich food materials could be applied to control the thermal behavior according to their amino acid compositions.

Since various vegetable sera contain free amino acids in appropriate quantities, with tomato serum abundantly containing Glu as a free amino acid ${ }^{18)}$ it can be expected that vegetable sera could be applied to control the gelatinization and retrogradation behavior of starch. In this study, the vegetable sera from tomato, carrot and red bell pepper (RBP) were selected as amino acid-rich food materials, and applied to clarify the potential control of the thermal behavior of potato starch granules, in terms of GT, viscosity, and turbidness by adding the vegetable sera.

\section{MATERIALS AND METHODS}

Materials. Large granules of potato starch (Hokuren 
Research Institute, Sapporo, Japan) were used after being repeatedly washed with distilled water at $4^{\circ} \mathrm{C}$ and airdried (moisture of the recovered starch, 14.0\%). Three kinds of vegetable serum were prepared. Tomato, carrot and RBP were each well crushed, and immediately centrifuged at about $12,000 \times g$ for $10 \mathrm{~min}$. Each resulting supernatant was lyophilized to obtain the respective vegetable serum preparations (tomato, carrot and RBP). All other reagents used were commercially available.

Differential scanning calorimetry (DSC). A tomato, carrot, or RBP solution $(10 \mu \mathrm{L})$ containing 5-20\% (w/w) of each vegetable serum based on the dry starch weight, which had been adjusted to pH 7.0 with $0.1 \mathrm{M} \mathrm{NaOH}$, was added to $5 \mathrm{mg}$ of potato starch in an airtight anodized aluminum capsule. DSC was conducted to determine the gelatinization temperature (GT) and enthalpy change of gelatinization in the range of $5-100^{\circ} \mathrm{C}$ at a heating rate of $2 \mathrm{~K} / \mathrm{min}$ by using an SSC-5020 DSC-6100 instrument (SII NanoTechnologies, Tokyo, Japan) as previously described. ${ }^{19)}$ Distilled water $(15 \mu \mathrm{L})$ was used as a reference, and triplicate measurements for each sample were performed. DSC for the starch samples preserved at $4^{\circ} \mathrm{C}$ for 7 days after the first DSC measurement was also carried out to evaluate the re-gelatinization enthalpy as an index of relatively long-term retrogradation. The RBP and tomato solutions were each supplemented with sucrose to adjust the total sugar content to that of the carrot solution.

Viscosity measurement. After adding $25 \mathrm{~mL}$ of the tomato, carrot or RBP solution containing 5, 10, 15 and $20 \%$ (w/w) of each vegetable serum based on the dry starch weight, which had been adjusted to $\mathrm{pH} 7.0$ with $0.1 \mathrm{M} \mathrm{NaOH}$, to $2.0 \mathrm{~g}$ of potato starch in an aluminum container, an RVA Super 3 Rapid Viscoanalyzer ${ }^{\mathrm{TM}}$ (Newport Scientific Pty., Ltd., Australia) was used to investigate the pasting properties. Each sample was held at $50^{\circ} \mathrm{C}$ for $1 \mathrm{~min}$, and then heated to $95^{\circ} \mathrm{C}$ at a heating rate of $5.6 \mathrm{~K} / \mathrm{min}$. After holding at $95^{\circ} \mathrm{C}$ for $2 \mathrm{~min}$, the sample was cooled to $50^{\circ} \mathrm{C}$ at a cooling rate of $5.6 \mathrm{~K} / \mathrm{min}$. The triplicate RVA measurements for potato starch had shown a high degree of reproducibility, the coefficient of variation of the peak viscosity being evaluated as only $0.19 \%$ $(159.2 \pm 0.3$ RVU, mean \pm SD $){ }^{11)}$ Each measurement was thus subsequently taken only once. The RBP and tomato solution were similarly supplemented with sucrose to adjust the total sugar content to that of the carrot solution.

Measurement of the absorbance of the retrograded paste. The paste after RVA measurement was held between two slide glasses separated by the thickness of one slide glass without any entrapped air bubbles, and left at $4^{\circ} \mathrm{C}$ for 1 day according to the previously described method. ${ }^{17)}$ After being warmed to room temperature, the absorbance at $500 \mathrm{~nm}$ of the paste was measured to evaluate the turbidness due to macroscopic aggregation of the potato starch chains during short-term retrogradation.

Analytical methods. The moisture content was determined by heating a sample at $110^{\circ} \mathrm{C}$ until constant weight had been obtained. The total sugar content was measured by the phenol-sulfuric acid method ${ }^{20)}$ as glucose. The nitrogen content of each vegetable serum was measured by a 2400II CHNS/O Ultimate analyzer (PerkinElmer Co., Ltd., Tokyo, Japan) with acetoanilide used as the standard according to the method previously described. ${ }^{21)}$ The ash content was determined by incinerating the sample at $550^{\circ} \mathrm{C}$ until constant weight had been obtained. The free amino acid analysis of each vegetable serum was carried out by an L-8500 (A) automatic amino acid analyzer (Hitachi Ltd., Tokyo, Japan) after each vegetable serum solution had been diluted 5-20 times with 3\% 5-sulfosalicylic acid, and then passed through a $0.25-\mu \mathrm{m}$ membrane filter (Advantec, Tokyo, Japan).

\section{RESULTS AND DISCUSSION}

\section{Chemical features of the vegetable sera.}

The three kinds of vegetable serum were prepared from RBP, tomato and carrot by crushing, centrifuging, and lyophilizing each. The vegetable sera contained about 9$15 \%$ water, about $1.5-2.5 \%$ nitrogen consisting of free amino acids, about 49-60\% sugar as glucose probably consisting of glucose, fructose and sucrose, and about 13$19 \%$ ash (Table 1), suggesting some effect of sugar and free amino acids on the gelatinization and retrogradation behavior. The amino acid composition of the vegetable sera showed that tomato had a very high content (about $57 \mathrm{~mol} \%$ ) of such charged amino acids as Glu, aspartic acid, arginine, Lys and histidine, and a very low content of non-polar and hydrophobic amino acids, especially as-

Table 1. Proximate compositions of the vegetable sera (tomato, carrot and RBP).

\begin{tabular}{lcccc}
\hline $\begin{array}{c}\text { Vegetable } \\
\text { serum }\end{array}$ & $\begin{array}{c}\text { Water } \\
\text { content } \\
(\%)^{\mathrm{a}}\end{array}$ & $\begin{array}{c}\text { Nitrogen } \\
\text { content } \\
(\%)^{\mathrm{b}}\end{array}$ & $\begin{array}{c}\text { Sugar }^{\mathrm{c}} \\
\text { content } \\
(\%)^{\mathrm{b}}\end{array}$ & $\begin{array}{c}\text { Ash } \\
\text { content } \\
(\%)^{\mathrm{b}}\end{array}$ \\
\hline Tomato & $14.7 \pm 0.3$ & $2.23 \pm 0.01$ & $50.3 \pm 2.6$ & $19.1 \pm 3.2$ \\
Carrot & $8.5 \pm 0.5$ & $2.49 \pm 0.03$ & $59.9 \pm 3.9$ & $13.1 \pm 0.8$ \\
RBP & $9.3 \pm 0.2$ & $1.54 \pm 0.01$ & $48.7 \pm 5.6$ & $18.9 \pm 2.2$ \\
\hline
\end{tabular}

Mean $\pm \mathrm{SD}(n=3)$. ${ }^{\mathrm{a}}$ Based on the sample weight. ${ }^{b}$ Based on the dry weight. ${ }^{\circ}$ As glucose.

Table 2. Free amino acid compositions (mol \%) of the vegetable sera (tomato, carrot and RBP).

\begin{tabular}{lccc}
\hline Amino acid & Tomato & Carrot & RBP \\
\hline Glu & 33.8 & 8.2 & 4.1 \\
Asp & 19.5 & 7.5 & 14.6 \\
Arg & 1.3 & 12.9 & 3.3 \\
Lys & 1.4 & 0.9 & 1.4 \\
His & 1.1 & 1.3 & 1.4 \\
Asn & 8.5 & 24.4 & 47.4 \\
Gln & - & - & - \\
Ser & 2.6 & 2.7 & 6.0 \\
Thr & 2.3 & 3.0 & 4.1 \\
Tyr & 0.8 & 2.7 & 0.9 \\
GABA & 12.1 & 9.0 & 5.3 \\
Ala & 5.2 & 12.8 & 2.2 \\
Gly & 0.5 & 0.6 & 0.5 \\
Val & 5.0 & 5.4 & 2.9 \\
Leu & 1.2 & 2.0 & 1.4 \\
Ile & 1.0 & 3.3 & 1.1 \\
Pro & - & - & - \\
Phe & 2.8 & 2.9 & 2.0 \\
Met & 0.8 & 0.5 & - \\
Trp & - & - & -1.4 \\
Cys & - & 30.8 & - \\
CAA & 57.1 & & \\
\hline
\end{tabular}

GABA, $\gamma$-aminobutylic acid; CAA, charged amino acids. 
paragines. The charged amino acid content decreased in the following order: tomato > carrot > RBP (Table 2), suggesting a characteristic effect on the thermal behavior of starch depending on the charged amino acid content of the vegetable serum.

\section{Control of the gelatinization behavior.}

The thermal characteristics of the gelatinization of potato starch in a tomato, carrot or RBP solution with different concentrations were evaluated by DSC. In order to evaluate the effect of sugar in the vegetable sera preparations on GT, the effect of sucrose on GT of potato starch was first confirmed by DSC. GT $\left(T_{\mathrm{p}}\right)$ of the potato starch slightly increased from $62.7^{\circ} \mathrm{C}$ for the control without sucrose to $63.0^{\circ} \mathrm{C}$ with sucrose added to the same total sugar concentration as that in the carrot solution having the highest sugar concentration. Although this increase in GT was small, the sugar concentration of the RPB and tomato solutions was supplemented with sucrose to give the same total sugar concentration as that for the carrot solution in this study. $T_{\mathrm{p}}$ of the potato starch increased with increasing amount of each vegetable serum (Fig. 1), and the relationship between $T_{\mathrm{p}}(Y)$ and the added amount $(X)$ could be expressed by the following linear regression equations with a high coefficient of determination: $Y=$ $0.172 X+63.0\left(r^{2}=0.950\right)$ for tomato; $Y=0.137 X+63.0$ $\left(r^{2}=0.946\right)$ for RBP and $Y=0.153 X+62.9\left(r^{2}=0.972\right)$ for carrot. The slope of the linear regression curve is referred to as the TG - increase index ( $T_{\text {gel }}$ inc. index) according to the previous study, ${ }^{14)}$ because the slope repre-

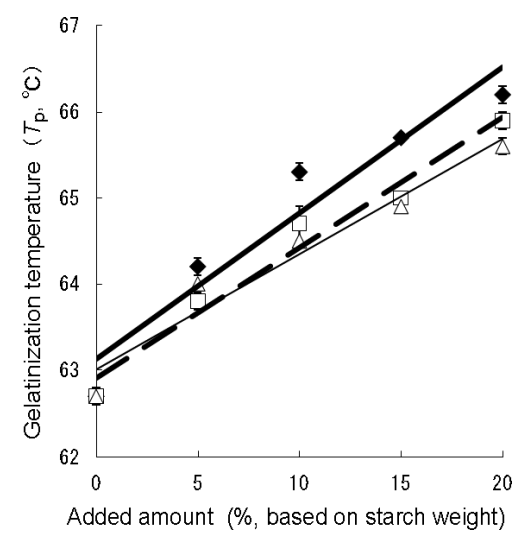

Fig. 1. Effect of vegetable sera on the gelatinization temperature $\left(T_{\mathrm{p}}\right)$ of potato starch evaluated by DSC.

$\checkmark$, tomato; $\square$, carrot; $\triangle$, RBP. Each value is the mean $\pm \operatorname{SD}(n=$ 3). Omitted error bars were too close to show.

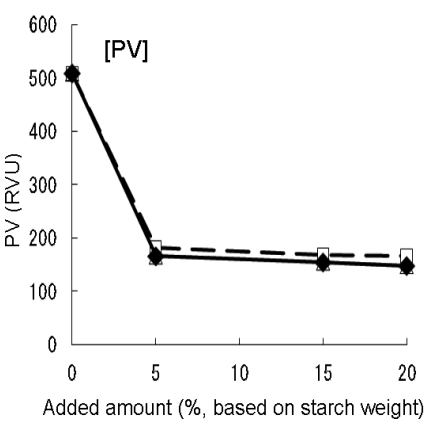

sents the extent of the increasing effect of a vegetable serum on TG. It became evident that the relationship between $T_{\text {gel }}$ inc. index $(Y)$ and the charged amino acid content $(X)$ of the vegetable serum could be expressed by the following linear regression equation with a high coefficient of determination: $Y=9.70 \times 10^{-4} X+0.119\left(r^{2}=\right.$ $0.915)$. This relationship strongly suggests that the contribution of a vegetable serum to GT of the potato starch would depend on the charged amino acid content of the vegetable serum. However, there was no significant difference between the enthalpy change $(14.7 \pm 5 \mathrm{~J} / \mathrm{g})$ of the control sample without a vegetable serum and that (14.9 \pm $0.2-15.4 \pm 4 \mathrm{~J} / \mathrm{g}$ ) of the vegetable serum-containing sample. A vegetable serum thus could not influence the enthalpy change of potato starch.

The pasting behavior of the potato starch was investigated by RVA in the presence of vegetable sera at several concentrations. Adding a vegetable serum to potato starch at the 5\% level substantially reduced the peak viscosity (PV), whereas above the 5\% level there was little further effect (Fig. 2). This suggests that a sufficient decrease in PV could be achieved by a small addition of a vegetable serum such as $5 \%$. However, a decrease in PV depending on the difference in charged amino acid contents of the vegetable sera was hardly apparent, because the inhibition of swelling of the potato starch granules probably approached the limitation with even $5 \%$ addition. The pasting temperature (PT) increased with increasing amount of added vegetable serum, in particular, adding to the 5\% level resulted in a marked increase (Fig. 2) corresponding to the added level resulting in the reduced PV. Corresponding to that for the reduced PV and elevated PT levels just described, breakdown (BD) also decreased with increasing amounts of added vegetable serum (Fig. 3), in particular, at the 5\% addition level, indicating stable viscosity of the potato starch paste. These RVA parameters hardly varied above the $15 \%$ addition level (to $23-37 \%$ addition, data not shown). It is thus concluded that adding a vegetable serum modified the gelatinization behavior, in terms of the increased gelatinization temperature and reduced viscosity of the potato starch paste due to the inhibition of swelling of the starch granules, suggesting a contributive effect to improving the sticky and pasty texture.

\section{Control of the retrogradation behavior.}

The effect of tomato, carrot and RBP on the initial retrogradation behavior was evaluated by the setback (SB)

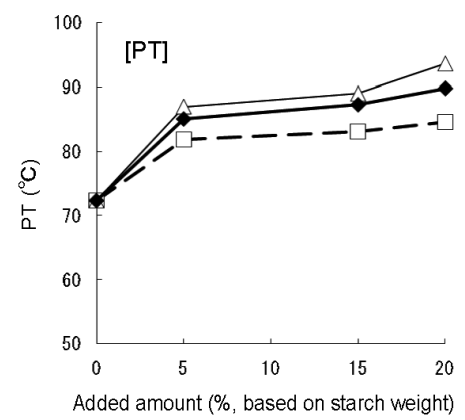

Fig. 2. Effect of vegetable sera on the peak viscosity value (PV) and peak temperature (PT) of potato starch evaluated by RVA. , tomato; $\square$, carrot; $\triangle$, RBP 

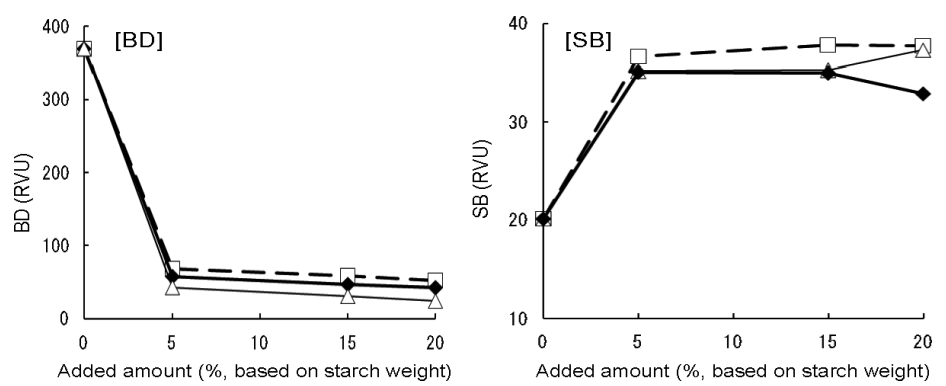

Fig. 3. Effect of vegetable sera on the breakdown (BD) and setback (SB) values of potato starch evaluated by RVA.

$\checkmark$, tomato; $\square$, carrot; $\triangle$, RBP.

during cooling to $50^{\circ} \mathrm{C}$ with the RVA measurement. Adding any one of the three vegetable sera at the $5 \%$ level substantially elevated SB when compared with the control value, although there was little further increase by adding at above the 5\% level (Fig. 3). It has been reported that such amino acids as Lys, Glu, Gly and Ala, and PLs with different degrees of polymerization, in particular the charged amino acids, elevated SB. ${ }^{14)}$ Since the charged amino acids have high binding ability to starch chains, ${ }^{15}$ the increased SB with a vegetable serum was caused by entanglement of the dispersed starch chains, probably through electrostatic interaction among the starch chains and charged amino acids in the vegetable serum during the cooling process.

In order to easily analyze the effect of a vegetable serum on short-term retrogradation, starch pastes with a high concentration (26\% for tomato, $37 \%$ for RBP and $23 \%$ for carrot) of an added vegetable serum was used, because the RVA parameters were little changed by adding at a high concentrations $(23-37 \%)$ as compared with the effect for $5 \%$ addition (data not shown). After preserving at $4{ }^{\circ} \mathrm{C}$ for $24 \mathrm{~h}$ to form a gel, the absorbance at $500 \mathrm{~nm}$ was measured to evaluate the aggregation of the starch chains. The increase in absorbance of the starch paste containing a vegetable serum was higher than that for the control (Fig. 4), indicating that the vegetable serum accelerated aggregation during cooling. It is thus concluded that a vegetable serum would accelerate short-term retrogradation in terms of increased aggregation of the starch chains.

After DSC measurements for the first gelatinization, each sample was preserved at $4^{\circ} \mathrm{C}$ for 7 days to evaluate by DSC the extent of the ordered structure reconstituted during long-term preservation. The enthalpy change for re-gelatinization of the control showed $7.9 \pm 1.3 \mathrm{~J} / \mathrm{g}$ (Fig. 5), which corresponds to about $44 \%$ for that of the ordered structure of the native starch granule, indicating a reasonable degree of reconstitution of the ordered structure during preservation, because the degree of retrogradation for the gelatinized potato starch during preservation at $5^{\circ} \mathrm{C}$ for $2-10$ days could be estimated to be about $40 \%$ by DSC. ${ }^{22)}$ The addition of a vegetable serum significantly reduced the re-gelatinization enthalpy to about $50-60 \%$ of the control level, except when adding tomato above the $10 \%$ level and RBP at the $15 \%$ level, the decrease being independent of the addition level and of the charged amino acid content (Fig. 5). The results of this study suggest that $5 \%$ addition of a vegetable serum would be sufficient to inhibit relatively long-term retrogradation in

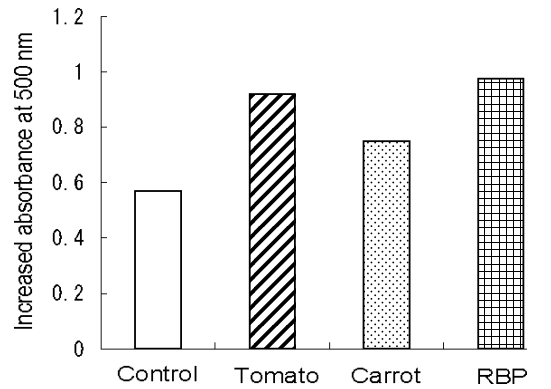

Fig. 4. Increased absorbance at $500 \mathrm{~nm}$ of potato starch paste containing a vegetable serum preserved at $4^{\circ} \mathrm{C}$ for $24 \mathrm{~h}$.

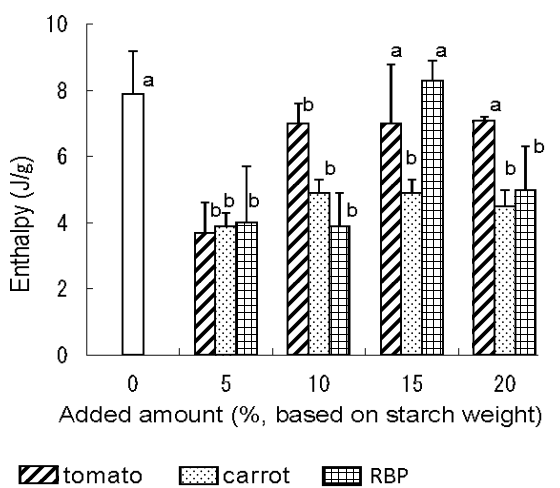

Fig. 5. Effect of vegetable sera on the re-gelatinization enthalpy of potato starch by DSC.

DSC was carried out on samples preserved at $4{ }^{\circ} \mathrm{C}$ for 7 days after the first DSC measurement. Error bars with different letters show the standard deviation of triplicate measurements and the significant difference $(p<0.05)$ by Student's $t$-test.

terms of decreasing the reconstitution of the ordered structure and entanglement and aggregation of the dispersed starch chains during initial and short-term preservation.

\section{CONCLUSION}

The gelatinization and retrogradation behavior of potato starch was evaluated in an aqueous system containing vegetable sera with different charged free amino acid contents prepared from tomato, carrot and RBP, in terms of the gelatinization temperature (GT), viscosity, turbidness, and re-gelatinization enthalpy. GT increased with increasing added amount of each vegetable serum, and the increased GT level was nearly dependent on the charged amino acid content of the vegetable serum. Markedly reduced viscosity and increased pasting temperature occurred with the small addition of a vegetable serum due to the inhibition of swelling. The increased setback, and reduced re-gelatinization enthalpy and transparency of the 
paste from adding a vegetable serum demonstrated a reduced reconstitution of the ordered structure and entanglement and aggregation of the dispersed starch chains during cooling. The results of this study should contribute to discrete control of the gelatinization and retogradation behavior of potato starch by adding a vegetable serum.

We are grateful to Associate Professor T. Hamanishi of Kyoritsu Women's University for measuring RVA, and to Mr. T. Itaya of Hokuren Research Institute for providing large-granule potato starch.

\section{REFERENCES}

1 ) K. Takahashi, K. Shirai, K. Wada and A. Kawamura: Effects of salts and saccharides on the gelatinization of starch. J. Jpn. Soc. Starch Sci., 27, 22-27 (1980).

2 ) K. Takahashi, K. Shirai and K. Wada: Relation between the gelatinization and the retained salt of starch. J. Jpn. Soc. Starch Sci., 28, 1-8 (1981).

3 ) K. Takahashi and K. Wada: Reversibility of salt effects on the thermal stability of potato starch granules. J. Food Sci., 57, 1140-1143 (1992).

4 ) D.G. Medcalf and K.A. Gilles: Effect of a lyotropic-ion series on the pasting characteristics of wheat and corn starches. Starch/Stärke, 18, 101-105 (1966).

5 ) B.M. Gough and J.N. Pybus: Effect of metal cations on the swelling and gelation behavior of large wheat starch granules. Starch/Stärke, 25, 123-130 (1973).

6 ) S. Lin, M.W. Breene and S.J. Sargen: Effects of $\mathrm{pH}$, sodium chloride, polysaccharides, and surfactants on the pasting characteristics of pea flours. Cereal Chem., 67, 14-19 (1990).

7 ) K. Kohyama and K. Nishinari: Effect of sugars on gelatinization and retrogradation of sweet potato starch. J. Agric. Food Chem., 39, 1406-1410 (1991).

8 ) C.-Y. Lii, V.M.-F. Lai, K.-F. Liu and W.-H. Chang: Influences of polyols on thermal and dynamic viscoelastic properties of rice starches during gelatinization. Starch/Stärke, 49, 346-354 (1997).

9 ) S.Y. Gerlsma: Gelatinization temperature of starch, as influenced by polyhydric and monohydric alcohols, phenols, carboxylic acids and some other additives. Starch/Stärke, 22, 3-9 (1970).

10) J. Singh, N. Singh and K. Saxenas: Effect of fatty acids on the rheological properties of corn and potato starch. J. Food Eng., 52, 9-16 (2002)

11) T. Yamagishi, M. Hattori, T. Yoshida and K. Takahashi: Improvement of the functional properties of sucrose stearate by phosphorylation. J. Agric. Food Chem., 52, 8039-8045 (2004).

12) X. Liang and J.M. King: Pasting and crystalline property differences of commercial and isolated rice starch with added amino acids. J. Food Sci., 68, 832-838 (2003).

13) A. Ito, M. Hattori, T. Yoshida and K. Takahashi: Reversible regulation of gelatinization of potato starch with poly(L-lysine) and amino acids. Starch/Stärke, 56, 570-575 (2004).

14) A. Ito, M. Hattori, T. Yoshida and K. Takahashi: Contribution of the net charge to the regulatory effects of amino acids and $\varepsilon$-poly(L-lysine) on the gelatinization behavior of potato starch granules. Biosci. Biotechnol. Biochem., 70, 76-85 (2006).

15) A. Ito, M. Hattori, T. Yoshida, A. Watanabe, R. Sato and K. Takahashi: Regulatory effect of amino acids on the pasting be- havior of potato starch is attributable to its binding to the starch chain. J. Agric. Food Chem., 54, 10191-10196 (2006).

16) K. Kinoshita, A. Ito, M. Hattori, T. Yoshida and K. Takahashi: Gelatinization behavior of potato starch granules through coupling two kinds of amino acids. J. Appl. Glycosci., 55, 89-93 (2008).

17) S. Katayose, K. Kegai, M. Nishimura, N.A. bt. Daud, M. Hattori, T. Yoshida, Y. Ishii and K. Takahashi: Starch- $\varepsilon$-poly(Llysine)-fatty acylated saccharide and $\varepsilon$-poly(L-lysine)-fatty acylated saccharide conjugates exhibit emulsifying ability, antibacterial activity, and controlling ability of thermal behavior of potato starch. J. Appl. Glycosci., 54, 173-180 (2007).

18) K. Zushi and N. Matsuzoe: Effect of soil water deficit on vitamin $\mathrm{C}$, sugar, organic acid, amino acid and carotene contents of large-fruited tomatoes. J Jpn. Soc. Horlt. Sci., 67, 927-933 (1998) (in Japanese).

19) K. Takahashi, K. Shirai and K. Wada: Melting behavior of gels prepared from isolated subunits of collagen. J. Food Sci., 53, 1920-1921 (1988).

20) M. Dubois, K.A. Gilles, J.K. Hamilton, P.A. Rebers and F. Smith: Colorimetric method for determination of sugars and related substances. Anal. Chem., 28, 350-356 (1956).

21) W. Yang, N. Komine, M. Hattori, Y. Ishii and K. Takahashi: Improvement of potato starch by conjugating with $\varepsilon$-poly $(\mathrm{L}-$ lysine) through the Maillard reaction. J. Appl. Glycosci., 52, 253-259 (2005).

22) F. Nakazawa, S. Noguchi, J. Takahashi and M. Takada: Retrogradation of gelatinized potato starch studied by differential scanning calorimetry. Agric. Biol. Chem., 49, 953-957 (1985).

野菜漿液により制御した馬鈴薯澱粉の糊化・老化挙動 高村百合子'，木下か抢る'，伊藤 梓'，服部 誠' 好田 正 $^{1}$ ，稲熊隆弘 ${ }^{2}$, 高橋幸資 ${ }^{1}$ ${ }^{1}$ 東京農工大学農学部応用生物科学科 (183-8509 府中市幸町 3-5-8)

2 カゴメ総合研究所

(329-2762 那須塩原市西富山 30)

馬鈴薯港粉粒の糊化抒よび老化挙動に及ぼすトマト， ニンジンおよび赤ピーマンから調製した荷電遊離アミノ 酸含量の異なる野菜漿液の特徵的な影響を示差走査熱量 測定，ラピッドビスコアナライザーおよび透明度による 評価結果から解析した。糊化温度 (GT) は, 各野菜漿液 の添加量に伴い上昇し, 上昇した GT は野菜漿液の荷電 アミノ酸含量に概敉依存した。各野菜漿液の少量の添加 で，膨潤の抑制によってピーク粘度およびブレークダウ ンは著しく低下し, 糊化温度が上昇した。野菜漿液の添 加は, セットバックおよび濁度の上昇をもたらし, 再糊 化エンタルピーをコントロールの約 50-60\% まで低下さ せた。このことは，野菜漿液が冷却過程で分散した澱粉 鎖の絡み合いや凝集に続く規則構造の再形成を減じたこ とを示唆する。 